\title{
Components of positive youth development among native students and students with an immigrant background in the Slovenian educational environment
}

\author{
Ana Mlekuž \\ Educational Research Institute, Ljubljana, Slovenia
}

\section{Abstract}

Several studies (Fuligni, 2004; Lerner et al., 2015; Wiium \& Dimitrova, 2019) show that a positive youth development model with the $5 \mathrm{Cs}$ (competence, confidence, character, connection, caring) effectively promotes positive aspects of adolescents' development. Adolescence is a period of accelerated physical, intellectual and emotional development that can be very stressful for the young, but even more so for young immigrants who confront several other obstacles connected to their background (e.g. discrimination, finding new friends, the language barrier etc.). The present paper examines the differences between native and immigrant students (first- and second-generation) within Slovenia's educational environment in self-assessed competencies, characteristics and skills based on the ${ }_{5} \mathrm{Cs}$ of the PYD model to determine that environment's success in providing the optimal conditions for immigrant students' adaptation. Students' self-assessed competencies between the groups were analysed on the Slovenian national PISA 2018 sample using the IEA International Database Analyzer (IEA IDB Analyzer). The results reveal the Slovenian environment does not provide optimal conditions for immigrants' adaptation and detected three areas in which Slovenian students need greater support: (1) first- and second-generation immigrants' self-efficacy; (2) second-generation immigrants' connection to their family, peers and teachers; and (3) native students' attitudes toward diversity. While this paper's findings are only preliminary, they may 
serve as a starting point for further research in finding effective ways to support positive youth development.

Keywords: immigrant background; positive youth development; PISA 2018; educational policies; Slovenia

Kazalniki pozitivnega razvoja mladih med učenci, pripadniki večinskega prebivalstva, in učenci priseljenci znotraj slovenskega izobraževalnega okolja

Povzetek

Številne študije (Fuligni, 2004; Lerner et al., 2015; Wiium \& Dimitrova, 2019) so pokazale, da model kazalnikov pozitivnega razvoja mladih ${ }_{5} \mathrm{C}$ (kompetentnost, samozavest, značaj, povezanost in skrb) učinkovito spodbuja pozitivne vidike razvoja mladostnikov. Mladostništvo je obdobje pospešenega telesnega, intelektualnega in čustvenega razvoja, ki je lahko zelo stresno za mlade, še posebej pa za mlade priseljence, ki se hkrati soočajo še $z$ drugimi ovirami, povezanimi z njihovim ozadjem (npr. diskriminacija, iskanje novih prijateljev, neznanje jezika itd.) Prispevek se osredotoča na razlike $\mathrm{v}$ samooceni kompetenc, značilnosti in veščin kazalnikov pozitivnega razvoja mladih med učenci, pripadniki večinskega prebivalstva, in učenci priseljenci prve in druge generacije, v kontekstu slovenskega izobraževalnega okolja, njegov namen pa je ugotoviti, na katerih področjih učenci potrebujejo več podpore pri zagotavljanju optimalnih pogojev za vključevanje učencev migrantov. Razlike $\mathrm{v}$ samooceni kompetenc med skupinami učencev smo analizirali na nacionalnem vzorcu mednarodne raziskave PISA 2018 s pomočjo programa IDB Analyzer. Rezultati so pokazali, da slovensko okolje ne zagotavlja optimalnih pogojev za uspešno vključevanje migrantov in opozarjajo na tri področja, kjer učenci potrebujejo več podpore: (1) zaznava samo-učinkovitosti učencev priseljencev prve in druge generacije, (2) povezanost učencev priseljencev druge generacije $z$ družino, vrstniki in učitelji ter (3) odnos učencev, pripadnikov večinskega prebivalstva, do raznolikosti. Čeprav so rezultati preliminarni, pa služijo kot temelj nadaljnjega raziskovanja tega področja ter iskanja načinov za podporo pozitivnega razvoja mladih.

Ključne besede: imigrantsko ozadje, pozitivni razvoj mladih, PISA 2018; izobraževalne politike; Slovenija.

Adolescence is a period in which young people experience great changes (physical, cognitive, social, emotional, interpersonal), which put them under considerable stress. Such pressure is even greater for young people 
with an immigrant background since they face several other obstacles like discrimination, learning a new language, finding money for survival, and creating new social networks (Wigfield et al., 2006). As a result, such adolescents might feel socially isolated and even drop out from school (CorreaVelez et al., 2017). However, the very difficult circumstances these students face might also lead them to develop a more flexible personality and thereby strengthen their well-being (Fuligni, 2004; Quintana et al., 2006). Many studies focus on the educational gap between native students and students with an immigrant background in terms of academic achievement (Levels et al., 2008; Schleicher, 2015; Schnepf, 2007). Still, not many studies have considered differences between immigrant and native students in other dimensions of personal development and well-being like self-awareness, cognitive flexibility, and resilience.

The main aim of this article is therefore to explore differences in the personal resources and developmental assets of native and immigrant 15-year-old students in Slovenia. First, the theoretical background on positive youth development relative to immigrant status and the context of Slovenia's educational environment are presented. The paper then tries to connect and explain elements of positive youth development and differences in personal resources and developmental assets between native and immigrant students in Slovenia's educational environment.

\section{Immigrant background as a framework for positive youth development}

It is not completely clear whether an immigrant background is a risk factor in terms of personal development, acculturation and overall psychological well-being since several studies (Brough et al., 2003; Correa-Velez et al., 2017; Motti-Stefanidi \& Masten, 2017) in this field show mixed results. On one hand, these students often come from low-socioeconomic backgrounds, face discrimination and racism, are socially isolated and more often diagnosed with mental health problems (Correa-Velez et al., 2017; Fazel et al., 2005). On the other hand, these children may develop a certain level of adaptability and flexibility skills, such as establishing friendships with individuals from diverse backgrounds, learning new languages, forming new identities which can quickly shift the norms and values of original and adopted countries, and develop ways to manage their emotions. Moreover, 
first-generation immigrant students ${ }^{\mathrm{I}}$ often even demonstrate optimism for the future despite their sometimes very troubled past (Brough et al., 2003; Nunn et al., 2014).

The phenomenon whereby first-generation immigrants' adaptation is more successful than that of second-generation immigrants and even natives is called the "immigrant paradox" and (Garcia-Coll \& Marks, 2012) has mostly been explored in the USA and Canada, less so in Europe (Dimitrova et al., 2017). The phenomenon of immigrants displaying more adaptation problems and less favourable outcomes (e.g. higher rates of psychological problems, school difficulties and disruptive behaviours) compared to natives is named "migration morbidity" (ibid.). Both phenomena were explored in a research review of 102 studies conducted in 14 European countries by Dimitrova and colleagues (2017). Even though the review provided mixed results for paradox and migration morbidity, it confirmed that immigrant youth's successful adaptation depends on three aspects: (1) close family and peer relationships, classmate support and supportive neighbourhoods; (2) perceived discrimination; and (3) adoption of both the host and their own ethnic culture, while at the same time keeping a strong ethnic identity and maintaining their culture.

While exploring young immigrants' positive youth development, the questions of who adapts successfully and what are the preconditions for success remain unanswered (Motti-Stefanidi, 2017). One model which effectively promotes positive aspects of adolescents' development and is used by several researchers to explore this area is the ${ }_{5} \mathrm{Cs}$ of the Positive Youth Development (PYD) model (Fuligni, 2004; Kozina \& Pivec, 2020; Lerner et al., 2012, 2015; Wiium \& Dimitrova, 2019). Although a number of models of positive youth development exist, the ${ }_{5} \mathrm{Cs}$ model is the most empirically supported and most commonly used as the framework for programmes supporting positive youth development (Heck \& Subramaniam, 2009). Due to its flexibility in various contexts, in the present study this model was chosen as a framework to explore differences in perception of the ${ }_{5} \mathrm{Cs}$ between native students, second-generation immigrants and first-generation immigrants in Slovenia.

PYD emphasises the importance of identifying and supporting strengths rather than preventing or treating deficits, which proves to be

1 First-generation immigrant students are foreign-born students whose parents are foreign-born as well, whereas second-generation immigrant students are born in the country of destination, while their parents are foreign-born. 
a more effective way of enhancing positive development and resilience (Masten, 2014). It focuses on the positive, instead of the negative, resources that adolescents possess that can optimise their well-being, personal development and life experiences if they are strengthened, applied and supported appropriately (Lerner et al., 2015).

Benson (2006) classified personal resources as developmental assets and divided them into two larger groups: internal and external assets. Internal assets include positive values, social competence, a commitment to learning and a positive identity, whereas external assets comprise support, empowerment, boundaries and expectations. Lerner et al. (2015), on the other hand, propose five indicators of positive development known as the 5 Cs of PYD (competence, confidence, connection, character, caring) that are assumed to be interrelated. They reflect Benson's developmental assets and are defined as follows (Bowers et al., 2010):

- Competence is understood as a positive view of one's actions in specific areas, such as social, academic, cognitive and vocational settings.

- Confidence is defined as an internal sense of overall positive selfworth and self-efficacy, a positive identity and one's global self-regard, as opposed to domain-specific beliefs.

- Connection refers to positive relationships and bonds between the individual, people and institutions. These relationships and bonds are bidirectional and encompass exchanges between the individual and peers, family, school and community in which both parties contribute to the relationship.

- Character includes respect for societal and cultural rules, awareness and internalisation of standards of appropriate and correct behaviour, a sense of morality and integrity.

- $\quad$ Caring represents a sense of sympathy and empathy for others and the ability to see beyond oneself.

It is assumed that the individual interacts with their surrounding social environment through their resources and characteristics. These interactions go both ways and affect an individual's personal development and functioning (Lerner, 2007). 


\section{Students with an immigrant background in the Slovenian educational environment}

Many students in Slovenia with an immigrant background belong to the ethnicities of the countries of former Yugoslavia. In most cases, these students and/or their parents are economic migrants and/or refugees who came to Slovenia during the war in the Balkans and then remained (Ribičič, 2004; Vižintin, 2014). In recent years, however, the number of refugees coming to Slovenia from the Middle East (EMN, 2017) has been growing as well. In general, immigrant students come from families with a lower socioeconomic status (Cankar \& Zupanc, 2020).

Slovenia has only become a country of immigration in the last few decades and thus still struggles to establish the appropriate mechanisms for promoting a supportive environment for newcomers. In Slovenia, immigrants enjoy equal rights, but not equal opportunities. The Slovenian approach to integration negatively affects attitudes toward immigrants such that they are seen as strangers, not as equals. In addition, education is one area where the social integration of migrant students is not sufficiently supported (MIPEX, 2019). First-generation immigrant students are granted basic rights to compulsory education and several support mechanisms, such as learning of the Slovenian language and additional professional assistance (e.g. remedial classes, individual learning support, and tutoring). Moreover, a two-stage model with introductory and follow-up workshops during the adaptation period are in place for newly arrived immigrant students (Mlekuž \& Vršnik Perše, 2019). There are also several very effective good practices at schools and different national and international projects, funded by the government, which offer support for immigrant students, their parents and their teachers (Gril et al., 2021; Mlekuž \& Vršnik Perše, 2019; Vižintin, 2017). These support measures are meant for first-generation and not second-generation immigrant students.

It is observed that students with an immigrant background (first- and second-generation) more commonly enrol in short upper secondary vocational education programmes and less commonly in the more socially desirable upper secondary vocational education programmes (Cankar \& Zupanc, 2020; Skubic Ermenc, 2015). Further, a longitudinal survey of students' achievements at national tests reveals that first-generation immigrant students achieve lower scores in mathematics than second-generation immigrant students and both groups of students achieve lower scores than native students. This is true even when the results are controlled for 
students' socio-economic status (Cankar \& Zupanc, 2020). First-generation immigrant students are even frequently considered as students with special needs (Skubic Ermenc, 2015).

Besides institutional discrimination in education, first- and second-generation immigrant youth of an ex-Yugoslavian ethnicity face prejudice, stereotypes and ethnic discrimination in the spheres of work, social and political participation, access to the media and everyday life, all strongly embedded in Slovenian society (Kralj, 2008, 2014). Moreover, since 2015 prejudice against refugees and Muslims has been becoming stronger (Faces of Migration, 2020). The ICCS 2016 and PISA 2018 survey results show that Slovenian students hold less favourable attitudes to immigrants than the international averages in both surveys (Klemenčič et al., 2019; Pedagoški inštitut, 2020).

Research into the personal or developmental assets of immigrant students (compared to native students) in Slovenia is very scarce, with only three being found:

First, the results of a survey (Slodnjak et al., 2002) among Slovenian adolescents and refugee students from Bosnia showed that Slovenian students had lower self-esteem and greater feelings of inadequacy in the academic field, they did not feel loved and more often expressed suicidal thoughts. Bosnian refugees were more often sad, worried about the future and physical pain, yet their achievements were not lower than the native students' nor did they engage in externalising behaviour more than their native peers.

Second, a case study was conducted at a high school centre in Velenje concerning ethnic identity and language use among all students (Peer \& Medica, 2017). During the interviews, while students with an immigrant background were less prone to answer the questions about their ethnic identity, had no problems answering which languages they spoke, and chose to speak in the Slovenian language if a Slovenian was present. The authors speculated that the question on ethnic identity was closely connected to the fact that for students with an immigrant background their non-Slovenian ethnic identity was mostly developed and maintained in private life, whereas public life was generally connected to a Slovenian ethnic identity. Further, by choosing to speak in the Slovenian language the students with an immigrant background expressed a level of pragmatism, showing flexible and innovative identities. 
In the third study, a Slovenian sample of students formed part of a larger sample of students from 29 European countries (Delaruelle et al., 2021). The results reveal that first- and second-generation immigrants reported higher levels of life dissatisfaction and psychosomatic symptoms than their native peers. The results varied across schools and countries. Further, the results also showed that social capital, peer and family support provided better protection against poor mental health for students with an immigrant background.

It can be seen that even if Slovenia's educational environment does provide equal rights and language learning and learning support to firstgeneration immigrant students, it is lagging behind in successful inclusion and in providing equal opportunities for all students with an immigrant background. It can also be observed that intercultural dialogue in the school environment between the majority population and immigrant students is missing (Vižintin, 2014, 2017). With high levels of discrimination, the social environment does not favour students with an immigrant background and only permits the expression of a non-native ethnic identity in the private sphere of an individual's life.

\section{Aim of the study}

The focus of this paper is the positive development of adolescent students with an immigrant background in Slovenia. The paper examines the outcomes of native and immigrant students (first- and second-generation) as defined by the PISA survey in self-assessed competencies, characteristics and skills based on the $5 \mathrm{Cs}$ of the PYD model in the context of Slovenia's educational environment. The overall goal of the paper is to determine which personal resources students with an immigrant background possess in comparison to their native peers. More specifically, this paper seeks to explore the differences in means of self-reported indicators of the $5 \mathrm{Cs}$ between native students, second-generation immigrants and first-generation immigrants included in the Slovenian PISA 2018 survey. Since Slovenia's educational environment does not provide optimal conditions for the adaptation of immigrant youth, as defined by Dimitrova et al. (2017), we expect

2 Native students: student and at least one parent born in the country of assessment; First-generation immigrant students: student and both parents born outside the country of assessment; Second-generation immigrant students: student born in the country of assessment, the student's parent(s) born in another country (OECD, forthcoming-a). 
the analysis will expose mixed results with a certain level of migrant morbidity for Slovenian students with an immigrant background.

\section{Method}

\section{Participants}

The current study uses the Slovenian PISA 2018 student representative sample that involved 6,401 students aged between 15 and 16 years. The study focuses on the PISA sample of 15-year-old students regardless of their grade levels and the type of institution they were enrolled in and whether they were enrolled in full- or part-time education. Regarding the sample, $49 \%$ of the students were female and 51\% male, with a mean age of 15 years and 8 months. Their average achievement score for the PISA cognitive reading test was 495 points, which is above the OECD average of 487 points. First- and second-generation immigrant students represented just $9 \%$ of the whole sample of students (see Table 1).

\section{Table 1: Sample characteristics by native and immigrant background.}

\begin{tabular}{lccc}
\multirow{2}{*}{ Background } & $\mathrm{N}$ & \multicolumn{2}{c}{ Gender } \\
\cline { 3 - 4 } & & Female \% (s. e.) & Male \% (s. e.) \\
Native & 5,730 & $49(0.48)$ & $51(0.48)$ \\
\hline Second-generation immigrants & 250 & $45(3.68)$ & $55(3.68)$ \\
\hline First-generation immigrants & 323 & $49(3.38)$ & $51(3.38)$ \\
\hline
\end{tabular}

Note: s. e. - standard error

\section{Instruments and included variables}

Each sampled student answered a cognitive test and a background questionnaire. Since PISA is a large-scale comparative study, the background questionnaires undergo a thorough quality assurance process (review by the countries, cognitive labs, linguistic translatability assessment, centralised transfer of trend material, negotiation of adaptations and linguistic verification), which provides for the data's comparability across countries and different cultural contexts. This assures the constructs used can be applied to other cultures and that different cultural contexts are considered (OECD, forthcoming-d).

PISA 2018 focused on reading competence, although it also assessed mathematics and science competencies. In addition, the 2018 PISA cycle included an evaluation of students' global competence (their ability 
to understand and appreciate the perspectives and world views of others) (OECD, 2019).

For the purposes of this analysis, we used several scales derived from items in the PISA 2018 background and global competence questionnaire ${ }^{3}$ $(\mathrm{OECD}, 2017)$ to describe each component in the ${ }_{5} \mathrm{Cs}$ model. The selection of the PISA scales and their attribution to the $5 \mathrm{Cs}$ was based on definitions of each of the ${ }_{5} \mathrm{Cs}$ (Bowers et al., 2010). Students' immigrant background was used as a grouping variable. All scales used were constructed using the IRT (item response theory) scaling methodology and transformed to have a mean of $o$ and a standard deviation of 1 across OECD countries (OECD, forthcoming-a). Cronbach's alphas are reported for the whole sample and for three student groups in Table 2.

Immigrant background. Students were asked in which country they and their parents were born. They needed to answer this question for themselves, their mother and their father. Answers were then recoded into three categories: native students, second-generation immigrants, and first-generation immigrants (OECD, forthcoming-a).

\section{Competence}

Self-concept of reading: Perception of competence. Students were asked how strongly (strongly disagree; disagree; agree; strongly agree) they agreed with three statements (e.g. I am a good reader; I read fluently, etc.) about their reading competence and their text comprehension.

Perception of the difficulty of the PISA test. Students were asked about their level of agreement regarding three statements on the difficulty of the reading tasks presented to them in the PISA test they had taken previously (e.g. Many texts were too difficult for me; There were many words I could not understand, etc.). Students answered on a 4-point Likert scale (strongly disagree; disagree; agree; strongly agree).

Self-efficacy regarding global issues was measured with a six-item question on how easy the students thought it would be for them to explain or discuss several topics on global issues (e.g. climate change, economic crises, refugee crisis etc.) Students answered on a 4-point Likert scale (I couldn't

3 The questionnaire is available at the following link: https://www.oecd.org/pisa/data/ 2018database/CY7_201710_QST_MS_STQ_NoNotes_final.pdf

For more information, also see the Technical report at the following link: https:// www.oecd.org/pisa/data/pisa2018technicalreport/PISA2018_Technical-ReportChapter-16-Background-Questionnaires.pdf 
do this; I would struggle to do this on my own; I could do this with a bit of effort; I could do this easily).

\section{Confidence}

Resilience. Students were asked how strongly (strongly disagree; disagree; agree; strongly agree) they agreed with five statements on their capacity to successfully deal with and recover from stressful situations (e.g. I usually manage one way or another; I feel that I can handle many things at a time, etc.).

Eudaemonia: meaning in life. Students were asked how strongly (strongly disagree; disagree; agree; strongly agree) they agreed with three statements concerning the meaning of their life (e.g. My life has a clear meaning or purpose; I have discovered a satisfactory meaning in life, etc.).

Cognitive flexibility/adaptability. Students were asked how well the six statements on their capacity to adapt their behaviour to unusual situations, which also included intercultural situations, described them (e.g. I can deal with unusual situations; I can adapt easily to a new culture, etc.). The students answered on a 4-point Likert scale (very much like me; mostly like me; somewhat like me; not much like me; not at all like me).

\section{Connection}

Teacher support in test language lessons was measured with a four-item question on how often teachers offered support to students in Slovenian language lessons (e.g. The teacher shows an interest in every student's learning; The teacher gives extra help when students need it, etc.). Students answered on a 4-point Likert scale (every lesson; most lessons; some lessons; never or hardly never).

Perception of co-operation at school. Students were asked to assess how true four statements on cooperation among students were for their school (e.g. Students seem to value cooperation; It seems that students are cooperating with each other, etc.). Students answered on a 4-point Likert scale (not at all true; slightly true; very true; extremely true).

Parents' emotional support perceived by the student. Students were asked to assess to what extent they agreed (strongly disagree; disagree; agree; strongly agree) with three statements about their perceived emotional support from their parents (e.g. My parents support my educational 
efforts and achievements; My parents support me when I am facing difficulties at school, etc.).

Subjective well-being: Sense of belonging to school. Students were asked to assess to what extent they agreed (strongly disagree; disagree; agree; strongly agree) with six statements on their sense of connection and belonging to school (e.g. I make friends easily at school; I feel like I belong at school, etc.).

\section{Character}

Student's attitudes towards immigrants was measured with a four-item question on the level of agreement with statements about immigrants' civic rights (e.g. immigrants should have the same opportunities for education, the opportunity to vote in elections, the same rights as everyone, etc.). Students answered on a 4-point Likert scale (strongly disagree; disagree; agree; strongly agree).

Respect for people from other cultures. Students were asked to assess how well five statements on respect for people from other cultures in terms of equality, respect for their values and their valuing of the expression of their cultures described them (e.g. I respect people from other cultures as equal human beings; I respect the values of people from different cultures, etc.). Students answered on a 5-point Likert scale (very much like me; mostly like me; somewhat like me; not much like me; not at all like me).

Global-mindedness was defined as a worldview in which one sees oneself as connected to the world community and feels a sense of responsibility towards its members (OECD, forthcoming-a). It was measured with a sixitem question where students needed to answer to what extent they agreed with several statements describing the sense of activism and responsibility for different issues in the (world) community (e.g. poor living conditions; companies that are known to provide poor workplace conditions; the global environment, etc.). Students answered on a 4-point Likert scale (strongly disagree; disagree; agree; strongly agree).

\section{Caring}

Perspective-taking. Students were asked to assess how well five statements on how far a student takes the perspective of others in different situations (e.g. to look at everybody's side of a disagreement, to understand my friends better by imagining how things look from their perspective etc.) 
described them. Students answered on a 5-point Likert scale (very much like me; mostly like me; somewhat like me; not much like me; not at all like me).

Awareness of intercultural communication. The students were asked to imagine themselves in a situation where they are talking in their native language to people whose native language is different from theirs. They were then asked to what extent they agreed with the statements on their observations and monitoring of the conversation (e.g. observing the reactions, checking the understanding, giving concrete examples), on how careful they are while expressing their meanings (e.g. listening carefully, choosing words carefully) and on the success of their management of communication breakdowns (e.g. using other means of communication when a problem with communication arises). Students answered a seven-item question on a 4-point Likert scale (strongly disagree; disagree; agree; strongly agree).

\section{Procedure}

PISA uses a two-stage stratified sampling design. In Slovenia, in the first stage all schools and educational programmes with 15-year-old students enrolled are included by default and thus 302 secondary education institutions, 43 basic school institutions and 2 adult education intuitions were sampled (Pedagoški inštitut, 2019).

In the second stage, around 42 15-year-old students within each school included were sampled. Students within the school were sampled with equal probability from the list of all eligible students at school. When there were fewer than 42 eligible students at a school, all 15-year-old students at the school were sampled. These sampling procedures ensured the representativeness of the test population. It took approximately 35 minutes for students to respond to the student background questionnaire (OECD, forthcoming-b).

Ethical review and approval was not required since public databases of the PISA 2018 assessment were used in the study. Written informed consent to participate in the study was provided by the participants' legal guardians or next of kin. Data collection for OECD-PISA studies is the responsibility of governments in the participating countries. 
Table 2: Cronbach's alphas for the whole sample and by student groups.

\begin{tabular}{|c|c|c|c|c|}
\hline & \multicolumn{4}{|c|}{ Cronbach's alpha } \\
\hline & $\begin{array}{l}\text { Whole } \\
\text { sample }\end{array}$ & $\begin{array}{l}\text { Native } \\
\text { students }\end{array}$ & $\begin{array}{c}\text { First-genera- } \\
\text { tion immi- } \\
\text { grants }\end{array}$ & $\begin{array}{l}\text { Second-gene- } \\
\text { ration immi- } \\
\text { grants }\end{array}$ \\
\hline \multicolumn{5}{|c|}{ Competence } \\
\hline $\begin{array}{l}\text { Self-concept of reading: Per- } \\
\text { ception of competence }\end{array}$ & 0.79 & 0.79 & 0.79 & 0.73 \\
\hline $\begin{array}{l}\text { Perception of the difficulty of } \\
\text { the PISA test }\end{array}$ & 0.87 & 0.86 & 0.89 & 0.86 \\
\hline $\begin{array}{l}\text { Self-efficacy regarding glo- } \\
\text { bal issues }\end{array}$ & 0.88 & 0.88 & 0.90 & 0.86 \\
\hline \multicolumn{5}{|c|}{ Confidence } \\
\hline Resilience & 0.80 & 0.80 & 0.78 & 0.83 \\
\hline Eudaemonia: Meaning in life & 0.89 & 0.89 & 0.91 & 0.92 \\
\hline $\begin{array}{l}\text { Cognitive flexibility/adap- } \\
\text { tability }\end{array}$ & 0.83 & 0.84 & 0.84 & 0.83 \\
\hline \multicolumn{5}{|c|}{ Connection } \\
\hline $\begin{array}{l}\text { Teacher support in test langu- } \\
\text { age lessons }\end{array}$ & 0.85 & 0.85 & 0.86 & 0.87 \\
\hline $\begin{array}{l}\text { Perception of co-operation } \\
\text { at school }\end{array}$ & 0.89 & 0.91 & 0.92 & 0.92 \\
\hline $\begin{array}{l}\text { Parents' emotional support } \\
\text { perceived by the student }\end{array}$ & 0.85 & 0.85 & 0.89 & 0.84 \\
\hline $\begin{array}{l}\text { Subjective well-being: Sense } \\
\text { of belonging to school }\end{array}$ & 0.80 & 0.80 & 0.82 & 0.81 \\
\hline \multicolumn{5}{|c|}{ Character } \\
\hline $\begin{array}{l}\text { Student's attitudes to immi- } \\
\text { grants }\end{array}$ & 0.86 & 0.85 & 0.92 & 0.92 \\
\hline $\begin{array}{l}\text { Respect for people from other } \\
\text { cultures }\end{array}$ & 0.94 & 0.94 & 0.95 & 0.94 \\
\hline Global-mindedness & 0.83 & 0.82 & 0.88 & 0.83 \\
\hline \multicolumn{5}{|c|}{ Caring } \\
\hline Perspective-taking & 0.83 & 0.83 & 0.84 & 0.84 \\
\hline $\begin{array}{l}\text { Awareness of intercultural } \\
\text { communication }\end{array}$ & 0.90 & 0.90 & 0.93 & 0.91 \\
\hline
\end{tabular}

\section{Statistical analyses}

Data were analysed using the statistical programme IEA IDB Analyzer (Version 4.0.39). Due to the two-stage sampling in the study, this programme uses individual student weights (W_FSTUWT) and sample weights. In this way, it can properly assess the standard parameter errors in the population using the Bootstrap method (OECD, forthcoming-c). The results were computed using "correlations" and "percentage and means". 
Table 3: Descriptive statistics and correlation coefficients for the $5\left(\mathrm{~s}^{\prime}\right.$ variables.



Note: Data were weighted with a Final trimmed nonresponse adjusted student weight (W_FSTUWT). All correlation coefficients in the table are statistically significant. Missing values were excluded from the analysis. 
To compute differences between groups, the IDB Analyzer uses a t-test taking sample dependency into account (IEA, 2016). Since the IDB Analyzer cannot perform a Bonferroni correction, it was not included in the analysis.

\section{Results}

Table 3 presents the means, standard deviations and Pearson correlation coefficient for the variables used in the analyses. All variables are significantly correlated in the expected way. Namely, all variables are positively correlated, except for the Perception of the difficulty of the PISA test, which is negatively correlated to all the other variables.

In Table 4, the means and standard deviations of the scales used by the student groups organised by the $5 \mathrm{Cs}$ are presented.

The results (see Table 4) show first-generation immigrants reporting lower levels of reading competence than native students. Similarly, first-generation immigrants believed the PISA test was more difficult than native students and second-generation immigrants did. On the other hand, there were no significant differences in the assessment of self-efficacy regarding global issues between native students and first-generation immigrants, although second-generation immigrants assessed their self-efficacy regarding global issues as significantly lower.

There were no significant differences between the student groups in assessing their capacity to pass through difficult situations and their self-assessed meaning in life. However, there was a significant difference in the self-assessment of cognitive flexibility/adaptability between first-generation immigrants and second-generation immigrants, where first-generation immigrants reported greater flexibility and adaptability in dealing with challenging or difficult situations (intercultural situations included) (see Table 4).

Second-generation immigrants reported the lowest perception of support from their teachers in their Slovenian language lessons as opposed to their native and first-generation immigrant peers. First-generation immigrants, on the other hand, reported the highest perception of support from their teachers in Slovenian language lessons, even higher than the native students. Similarly, second-generation students also reported the lowest perception of cooperation at the school, which is lower than the native students' perception. Yet, the first-generation students' perception of cooperation at the school does not differ from either native students' or second-generation immigrants' perception. Similarly, second-generation 
Table 4: Comparison of means and standard deviations by immigrant background by the $5 \mathrm{Cs}$.

\begin{tabular}{|c|c|c|c|c|}
\hline \multirow[t]{2}{*}{ Scale } & Native (1) & $\begin{array}{l}\text { Second-genera- } \\
\text { tion immigrants } \\
\text { (2) }\end{array}$ & $\begin{array}{l}\text { First-generation } \\
\text { immigrants }(3)\end{array}$ & \multirow{2}{*}{$\begin{array}{l}\text { Significant diffe- } \\
\text { rences between } \\
\text { groups }\end{array}$} \\
\hline & $\mathrm{M}(\mathrm{SD})$ & $\mathrm{M}(\mathrm{SD})$ & $\mathrm{M}(\mathrm{SD})$ & \\
\hline \multicolumn{5}{|l|}{ Competence } \\
\hline $\begin{array}{l}\text { Self-concept of reading: } \\
\text { Perception of compe- } \\
\text { tence }\end{array}$ & $0.10(0.91)$ & $0.02(0.92)$ & $-0.08(0.94)$ & $1>3$ \\
\hline $\begin{array}{l}\text { Perception of the diffi- } \\
\text { culty of the PISA test }\end{array}$ & $-0.05(0.94)$ & $-0.02(1.05)$ & $0.41(1.04)$ & $\begin{array}{l}1<3 \\
2<3\end{array}$ \\
\hline $\begin{array}{l}\text { Self-efficacy regarding } \\
\text { global issues }\end{array}$ & $-0.09(0.98)$ & $-0.30(1.08)$ & $-0.23(1.11)$ & $1>2$ \\
\hline \multicolumn{5}{|l|}{ Confidence } \\
\hline Resilience & $-0.05(0.96)$ & $-0.03(1.06)$ & $-0.03(1.05)$ & 1 \\
\hline $\begin{array}{l}\text { Eudaemonia: meaning } \\
\text { in life }\end{array}$ & $0.02(0.98)$ & $0.09(1.03)$ & $0.12(1.01)$ & / \\
\hline $\begin{array}{l}\text { Cognitive flexibility/ } \\
\text { adaptability }\end{array}$ & $-0.01(0.88)$ & $-0.05(0.92)$ & $0.12(1.00)$ & $2<3$ \\
\hline \multicolumn{5}{|l|}{ Connection } \\
\hline $\begin{array}{l}\text { Teacher support in test } \\
\text { language lessons }\end{array}$ & $-0.62(1.02)$ & $-0.72(1.14)$ & $-0.44(1.07)$ & $\begin{array}{l}1<3 \\
2<3\end{array}$ \\
\hline $\begin{array}{l}\text { Perception of co-opera- } \\
\text { tion at school }\end{array}$ & $-0.01(0.96)$ & $-0.28(1.04)$ & $-0.11(1.01)$ & $1>2$ \\
\hline $\begin{array}{l}\text { Parents' emotional } \\
\text { support perceived by } \\
\text { student }\end{array}$ & $-0.01(0.97)$ & $-0.30(1.01)$ & $-0.14(1.00)$ & $1>2$ \\
\hline $\begin{array}{l}\text { Subjective well-being: } \\
\text { Sense of belonging to } \\
\text { school }\end{array}$ & $-0.10(0.84)$ & $-0.08(0.80)$ & $-0.28(0.94)$ & $\begin{array}{l}1>3 \\
2>3\end{array}$ \\
\hline \multicolumn{5}{|l|}{ Character } \\
\hline $\begin{array}{l}\text { Student's attitudes to } \\
\text { immigrants }\end{array}$ & $-0.08(0.91)$ & $0.20(1.04)$ & $0.32(1.04)$ & $\begin{array}{l}1<2 \\
1<3 \\
2<3\end{array}$ \\
\hline $\begin{array}{l}\text { Respect for people from } \\
\text { other cultures }\end{array}$ & $-0.05(0.96)$ & $0.10(0.97)$ & $0.23(0.96)$ & $1<3$ \\
\hline Global-mindedness & $-0.09(0.94)$ & $-0.11(1.00)$ & $-0.25(1.09)$ & I \\
\hline \multicolumn{5}{|l|}{ Caring } \\
\hline Perspective-taking & $0.05(0.93)$ & $0.09(1.02)$ & $-0.01(1.10)$ & 1 \\
\hline $\begin{array}{l}\text { Awareness of intercul- } \\
\text { tural communication }\end{array}$ & -0.19 (0.94) & -0.17 (0.99) & $-0.20(1.08)$ & l \\
\hline
\end{tabular}

Note: Data were weighted with a Final trimmed nonresponse adjusted student weight (W_FSTUWT). The statistical difference between groups is computed using the t-test, where $|t|>1.96$ applies for statistically significant differences. Missing values were excluded from the analysis. 
immigrants reported the lowest parental emotional support among the three groups of students, although the difference is significant only for native students' perception. On the other hand, first-generation students reported the lowest sense of belonging to the school, whereas there were no significant differences in the sense of belonging to the school among the second-generation immigrants and native students (see Table 4).

As may be seen in Table 4, native students reported the most positive attitudes to working hard to achieve success at school and later in life (attitude to school: learning activities) among the three student groups, where the difference is significant only for first-generation immigrants. Firstgeneration immigrants also have the most positive attitudes to immigrants among all three groups (the difference is significant for all three groups). Moreover, this group of students also reported the highest respect for people from other cultures (the difference is significant only in comparison to native students). There are no significant differences in global-mindedness, which means there are no differences in students' connectedness to the world community and their sense of responsibility to its members.

There are no significant differences in the self-reported scales of the caring construct between the three student groups (see Table 4).

In general, first- and second-generation immigrants assess their own competence as lower than their native peers. In terms of confidence, there are no differences between the students, except in cognitive flexibility/adaptability, where first-generation immigrants reported greater flexibility/adaptability than second-generation students. In terms of connection, second-generation immigrants reported the lowest levels of connection with their teachers, peers and parents than their peers, although first-generation immigrants reported the lowest levels of belonging to the school among the three groups. As for character, first-generation immigrants show the most positive attitudes toward diversity among the three groups.

\section{Discussion}

Although, as expected, the analysis showed mixed results for the ${ }_{5} \mathrm{Cs}$, it is possible to draw certain common conclusions. Significant differences were found among native students, first- and second-generation immigrants in the self-assessed ${ }_{5} \mathrm{Cs}$ ' indicators that reveal interesting aspects of adolescents' development in the light of an immigrant background.

For example, the results for the competence component showed first-generation immigrant students assess the PISA test as more difficult 
than their peers do. One reason for this might be that the PISA 2018 test focused on reading comprehension of Slovenian texts, which is not a language in which immigrant students are proficient. The PISA results generally reveal that the gap between immigrant and native students is larger in reading achievement than in mathematics or problem-solving and associate this gap with the language barrier (Schleicher, 2015). Moreover, the lower perception of self-efficacy (self-efficacy regarding global issues, self-concept of reading) among students with an immigrant background in our survey could be attributed to the extent that other students with a similar background and their own struggles at school are observed because students with an immigrant background in Slovenia do not thrive compared to native students with respect to academic achievements.

There were no significant differences among the student groups concerning resilience and meaning of life. Still, the PISA 2018 results show that on average immigrant students are more resilient (OECD, 2019a) and express a weaker purpose in life than native students (OECD, 2019b). Nonetheless, first-generation immigrants express higher levels of cognitive flexibility/adaptability than their second-generation immigrant peers, which may be explained by the fact that first-generation immigrant students were directly exposed to two cultures, while their second-generation peers have grown up in Slovenia and thus had only indirect exposure to their cultural heritage. As shown in Peer and Medica's (2017) case study, the development and maintenance of immigrant students' non-Slovenian cultural identity are limited to the private sphere of their lives. This might affect their level of cognitive flexibility (Tadmor \& Tetlock, 2006).

As regards connection, Slovenian second-generation immigrants show the most concerning results. Their perception of teacher support, parental emotional support, and co-operation among students at the school is the lowest among all three student groups, which might indicate some level of social alienation. These results are even more concerning in the light of Wortley's (2009) findings that social alienation is a risk factor associated with immigrant youth criminality and Silber and Bhatt's (2007) process model of radicalisation where social alienation is one of the triggers for the pre-radicalisation phase.

First-generation immigrants, on the other hand, express the highest perception of teachers' support in Slovenian language lessons, which may be attributed to their poorer comprehension of the Slovenian language and the fact these students are entitled to different forms of support as part of 
the country's educational policies (Mlekuž \& Vršnik Perše, 2019). At the same time, these students express the lowest sense of belonging to school, which might be a due to discrimination and prejudice within the school environment and in wider Slovenian society.

On the contrary, as concerns the character component, it is the native students who come into the limelight by expressing the lowest levels of openness to multiculturalism given that their attitudes to immigrants and respect for people from other cultures are the least favourable among the three student groups. These findings confirm the general attitudes toward immigrants and diversity in Slovenia (Klemenčič et al., 2019; Kralj, 2008, 2014; Pedagoški inštitut, 2020). Several studies have corroborated the view that negative attitudes toward immigrants and other cultures are generally considered to be the origin of discriminative behaviour, bullying and harassment targeting immigrant students, which then affect such students' academic performance, motivation and well-being (Dessel, 2010; Glock, 2016), thereby making it important to shift students' attitudes to immigrants in the direction of being more open to diversity and multiculturalism.

We may conclude that the results regarding immigrant students' successful adaptation to the Slovenian environment are mixed and slightly inclined to migration morbidity, especially in the area of competence and connection, where the second-generation immigrant students are at a loss. These results also confirm that the Slovenian environment and policies do not provide the optimal conditions (as described by Dimitrova et al., 2017) for immigrant students' successful adaptation and point to the high level of discrimination, the lack of opportunities for immigrants to keep a strong ethnic identity, and their weak relational support at school and home.

\section{Limitations and Recommendations}

All things considered, we must bear in mind that this study was intended to be a preliminary one and, as such, is limited to use of the PISA background questionnaire whose primary function is not to test the PYD 5 Cs. To gain data more in line with the components of the PYD ${ }_{5} \mathrm{Cs}$, the ${ }_{5} \mathrm{Cs}$ questionnaire should be used to ensure comparability with similar studies relying on this instrument. Further, the Slovenian version of the PISA 2018 questionnaire did not specifically ask in which country an immigrant student's parents were born, meaning no control for country of origin was possible. This opens up new avenues for research on this topic based on differences among immigrant youth as well. It would also be interesting 
to explore how these $5 \mathrm{Cs}$ indicators predict risky behaviours and/or student achievement and whether in addition differences exist among these student groups in this area. Moreover, this paper should be regarded as a starting point for further research on the topic, especially in those areas where students in Slovenia need greater support, and thus as a platform for developing suitable and effective educational policies and effective PYD programmes for youth in the field of including immigrants in Slovenian society and their adaptation. Since the PISA 2018 database was used an international perspective, the paper could also be explored to shine a light on differences among young immigrants throughout European Union or OECD countries.

\section{Conclusion}

In this paper, differences between immigrant and native students' personal resources in terms of PYD were explored. The research's main aim was to identify differences in indicators of the $5 \mathrm{Cs}$ between native students, second-generation immigrants and first-generation immigrants to detect areas in need of special attention. Like with other surveys in this field (e.g. Dimitrova et al., 2017), while the results are mixed and somewhat inconclusive we can still highlight three areas where Slovenian students need more support: (1) first- and second-generation immigrants' self-efficacy; (2) second-generation immigrants' connection to their family, peers and teachers; and (3) native students' attitudes toward diversity. Given that all of these areas are interconnected, it is essential to support the weaker ones, which should also bring a positive effect to other areas and the well-being of all Slovenian students.

Nevertheless, considering the limitations on comparing the native and immigrant student groups, this paper's findings are merely preliminary and should only be seen as a starting point for further research on the topic, particularly in those fields where immigrant students need greater support. Such research would facilitate the identification of effective ways to support the positive youth development of adolescents with an immigrant background and to develop policies that ensure immigrants' optimal adaptation into the Slovenian education system and broader society.

To conclude, immigrant students' positive youth development depends on numerous factors, many of which are not fully controllable or easily defined. This makes it vitally important to further explore this field and bring attention to those aspects of youth development we can support 
and practices we can spread to the system level to thereby provide students with a platform on which they can thrive and develop to their full potential. The SIRIUS report concluded that the successful inclusion of immigrant students in Slovenian schools shares four common characteristics stemming from good practices, which may serve as guidance (Gril et al., 2021). Namely, to reduce discrimination and strengthening ethnic identity (1) multilingualism in schools should be recognised and considered. To strengthen relational support, (2) the entire school staff should be involved in Slovenian language classes for immigrants, which should be part of regular classes; (3) partnerships with the local environment; and (4) an open relationship of mutual trust and acceptance between all school stakeholders (students, teachers, parents, local community), which allows for responsiveness and adaptability to different situations should be established.

\section{Acknowledgements}

The Slovenian Research Agency supported this article as part of the project Positive Youth Development in Slovenia: Developmental Pathways in the Context of Migration (PYD-SI Model) [J5-1781].

\section{References}

Benson, P. L. (2006). All kids are our kids: What communities must do to raise caring and responsible children and adolescents. Jossey-Bass.

Bowers, E. P., Li, Y., Kiely, M. K., Brittian, A., Lerner, J. V., \& Lerner, R. M. (2010). The five Cs model of positive youth development: A longitudinal analysis of confirmatory factor structure and measurement invariance. Journal of youth and adolescence, 39(7), 720-735. https//doi.org/10.1007/ s10964-010-9530-9

Brough, M., Gorman, D., Ramirez, E., \& Westoby, P. (2003). Young refugees talk about well-being: A qualitative analysis of refugee youth mental health from three states. Australian Journal of Social Issues, 38(2), 193208. https//doi.org/10.1002/j.1839-4655.2003.tbo1142.x

Cankar, G., \& Zupanc, D. (2020). Pravične možnosti izobraževanja v Sloveniji; Populacijska raziskava o učencih s posebnimi potrebami, priseljencih in njihovim socialno-ekonomskim statusom $v$ povezavi $z$ dosežki $v$ šoli. Državni izpitni center. Accessed at: https://www.ric.si/mma/ Pravicne\%2omoznosti\%2oizobrazevanja\%20v\%2oSloveniji\%2odec.\%20 2020/2020122212462063/ 
Correa-Velez, I., Gifford, S. M., McMichael, C., \& Sampson, R. (2017). Predictors of secondary school completion among refugee youth 8 to 9 Years after resettlement in Melbourne, Australia. Journal of International Migration and Integration, 18(3), 791-805. https//doi.org/10.1007/s12134-016-0503-Z

Delaruelle, K., Walsh, S. D., Dierckens, M., Deforche, B., Kern, M. R., Currie, C., Maldonado, C. M., Cosma, A., \& Stevens, G. W. (2021). Mental Health in Adolescents with a Migration Background in 29 European Countries: The Buffering Role of Social Capital. Journal of Youth and Adolescence, 5o(5), 855-871. https//doi.org/10.1007/s10964-021-01423-1

Dessel, A. (2010). Prejudice in schools: Promotion of an inclusive culture and climate. Education and Urban Society, 42, 407-429. https//doi. org/10.1177/oo13124510361852

Dimitrova, R., Özdemir, S. B., Farcas, D., Kosic, M., Mastrotheodoros, S., Michałek, J., \& Stefenel, D. (2017). Is there a paradox of adaptation in immigrant children and youth across Europe? A literature review. In R. Dimitrova (Ed.), Well-being of youth and emerging adults across cultures: Novel approaches and findings from Europe, Asia, Africa and America (pp. 261-298). Springer. https//doi.org/10.1007/978-3-319-68363-8_18

EMN. (2017). Tujci v Sloveniji. Accessed at https://emm.si/migracije-in-slovenija/ tujci-v-sloveniji/

Faces of Migration. (2020). Migrants and Refugees in Slovenia 2020: Agenda 2030 and Migration - Report. Accessed at: https:/gcap.global/wp-content/ uploads/2021/o2/Faces-of-migration-2020-ENG.pdf

Fazel, M., Wheeler, J., \& Danesh, J. (2005). Prevalence of serious mental disorder in 7000 refugees resettled in western countries: A systematic review. The Lancet, 365(9467), 1309-1314. https//doi.org/10.1016/So140-6736(05)61027-6

Fuligni, A. J. (2004). The Adaptation and Acculturation of Children from Immigrant Families. In Gielen, U. P. \& Roopnarine, J. (Eds.), Advances in applied developmental psychology. Childhood and adolescence: Cross-cultural perspectives and applications (pp. 297-318). Praeger Publishers/Greenwood Publishing Group.

Garcia-Coll, C., \& Marks, A. K. (2012). The immigrant paradox in children and adolescents: Is becoming American a developmental risk?. American Psychological Association.

Glock, S. (2016). Does ethnicity matter? The impact of stereotypical expectations on in-service teachers' judgments of students. Social Psychology of Education, 19(3), 493-509. https//doi.org/10.1007/s11218-016-9349-7 
Gril, A., Autor, S., \& Žmavc, J. (2021). SIRIUS NRT 2020 - Prakse, ki uspešno implementirajo nove strategije vključevanja priseljencev in razvijajo večjezična šolska okolja v Sloveniji (Poročilo s posveta). Pedagoški inštitut. Accessed at https://www.pei.si/wp-content/uploads/2021/03/SIRISUS_ porocilo_2020.pdf

Heck, K. E., \& Subramaniam, A. (2009). Youth development Frameworks. University of California.

IEA. (2016). Help Manual for the IDB Analyzer. IEA. Accessed at https://www. csicr.cz/getattachment/40489916-3e56-45ef-9562-cd188obo478f/IDB_analyzer_help.pdf

Klemenčič, E., Mirazchiyski, P. V., \& Novak, J. (2019). Nacionalno poročilo Mednarodne raziskave državljanske vzgoje in izobraževanja (IEA ICCS 2016). Pedagoški inštitut. Accessed at https://www.pei.si/wp-content/uploads/2019/o1/nacionalno-porocilo-iccs.pdf

Kozina, A., \& Pivec, T. (2020). Contextual and Individual Predictors of Bullying and Victimization in Slovenia: Positive Youth Development Perspective. EREBEA. Revista de Humanidades y Ciencias Sociales, 10. https//doi. org/10.33776/erebea.v10io.4961

Kralj, A. (2008). When Ć Becomes Č: Discrimination of Unrecognized National Minorities in Slovenia. Revija za sociologiju, 39, 235-250. https:// hrcak.srce.hr/file/55461

Kralj, A. (2014). "To be accepted for who we are": The situation of unrecognized national minorities in Slovenia. In S. Caruana, L. Coposescu, \& S. Scaglione (Eds.), Migration, multilingualism and schooling in Southern Europe (pp. 63-73). Cambridge Scholars Publishing.

Lerner, R. M. (2007). The good teen. The Stonesong Press.

Lerner, R. M., Lerner, J. V., Bowers, E., \& Geldhof, G. J. (2015). Positive youth development: A relational developmental systems model. In Overton, W. F., \& Molenaar, P. C. (Eds.), Handbook of child psychology and developmental science. Vol. 1: Theory and method (pp. 607-651). Wiley.

Lerner, R. M., Lerner, J. V., Bowers, E. P., \& Lewin-Bizan, S. (2012). Thriving among immigrant youth: Theoretical and empirical bases of positive development. In Masten, A. S., Liebkind, K., \& Hernandez, D. J. (Eds.), The Jacobs Foundation series on adolescence. Realizing the potential of immigrant youth (pp. 307-323). Cambridge University Press.

Levels, M., Dronkers, J., \& Kraaykamp, G. (2008). Immigrant Children's Educational Achievement in Western Countries: Origin, Destination, and 
Community Effects on Mathematical Performance. American Sociological Review, 73(5), 835-853. https//doi.org/10.1177/000312240807300507

Masten, A. S. (2014). Global perspectives on resilience in children and youth. Child Development, 85(1), 6-20. https//doi.org/10.1111/cdev.12205

MIPEX. (2019). Slovenia 2019 - Key findings. Accessed at https://www.mipex. eu/slovenia

Mlekuž, A., \& Vršnik Perše, T. (2019). Policies Regulating Minority Education: The Case of Slovenia. Odgojno-obrazovne teme, 2(3-4), 69-92. https://hrcak.srce.hr/232083

Motti-Stefanidi, F. (2017). Conceptual and Methodological Approaches. Conceptual and Methodological Issues in the Study of Minority Youth: Adaptation and Development. In Cabrera, J., \& Leyendecker, B. (Eds), Handbook on Positive Development of Minority Children and Youth (pp. 1-3). Springer. https//doi.org/10.1007/978-3-319-43645-6

Motti-Stefanidi,F., \&Masten,A.S.(2017).AResiliencePerspectiveonImmigrants Youth Adaptation and Development. In Cabrera, J., \& Leyendecker, B. (Eds), Handbook on Positive Development of Minority Children and Youth (pp. 19-34). Springer. https//doi.org/10.1007/978-3-319-43645-6_2

Nunn, C., McMichael, C., Gifford, S. M., \& Correa-Velez, I. (2014). 'I came to this country for a better life': Factors mediating employment trajectories among young people who migrated to Australia as refugees during adolescence. Journal of Youth Studies, 17(9), 1205-1220. https//doi.org/10.1080 /13676261.2014.901496

OECD. (2017). Student questionnaire for PISA 2018 - Main survey version. Accessed at https://www.oecd.org/pisa/data/2018database/CY7_201710_ QST_MS_STQ_NoNotes_final.pdf

OECD. (forthcoming-a). Scaling procedures and construct validation of context questionnaire data. In OECD, PISA 2018 Technical Report. OECD Publishing. Accessed at https://www.oecd.org/pisa/data/pisa2018technicalreport/PISA2018_Technical-Report-Chapter-16-BackgroundQuestionnaires.pdf

OECD. (forthcoming-b). Sample design. In OECD, PISA 2018 Technical Report. OECD Publishing. Accessed at https://www.oecd.org/pisa/data/ pisa2018technicalreport/PISA2018\%20TecReport-Ch-04-Sample-Design. pdf

OECD. (forthcoming-c). Questionnaire Design and Computer-based Questionnaire Platform. In OECD, PISA 2018 Technical Report. OECD 
Publishing. Accessed at https://www.oecd.org/pisa/data/pisa2018technicalreport/PISA2018\%2oTecReport-Ch-17-BQ-Design.pdf

OECD. (forthcoming-d). Context Questionnaire Development. In OECD, PISA 2018 Technical Report. OECD Publishing. Accessed at https://www. oecd.org/pisa/data/pisa2018technicalreport/PISA2018-TecReport-Ch-03Context-Questionnaire-Development.pdf

OECD. (2019). PISA Assessment and Analytical Framework. OECD Publishing. Accessed at https//doi.org/10.1787/b25efab8-en

OECD. (2019a). PISA 2018 Results (Volume II): Where All Students Can Succeed. OECD Publishing. Accessed at https//doi.org/10.1787/b5fd1b8f-en

OECD. (2019b). PISA 2018 Results (Volume III): What School Life Means for Students' Lives. OECD Publishing. Accessed at https//doi.org/10.1787/ acd78851-en

Pedagoški inštitut. (2019). PISA 2018: Nacionalno poročilo s primeri nalog. Pedagoški inštitut. Accessed at https://www.pei.si/wp-content/uploads/2019/12/PISA2018_NacionalnoPorocilo.pdf

Pedagoški inštitut. (2020). Globalne kompetence učencev in učenk v raziskavi PISA 2018. Pedagoški inštitut. Accessed at: https://www.pei.si/wp-content/uploads/2020/10/Globalne-kompetence_okt2020.pdf

Peer, N., \& Medica, K. (2017). Ethnic and Linguistic Interactions of Adolescents at School Center Velenje. Monitor ISH, 19(1), 31-73. https//doi. org/10.33700/1580-7118.19.1.31-73(2017)

Quintana, S. M., Aboud, F. E., Chao, R. K., Contreras-Grau, J., Cross, W. E., Hudley, C., Hughes, D., Liben, L. S., Nelson-Le Galli, S., \& Vietze, D. L. (2006). Race, Ethnicity, and Culture in Child Development: Contemporary and Future Directions. Child Development, 77(5), 1129-1141. https//doi. org/10.1111/j.1467-8624.2006.00951.X

Ribičič, C. (2004). Ustavnopravno varstvo manjšinskih narodnih skupnosti v Sloveniji. Revus. Journal for Constitutional Theory and Philosophy of Law/Revija za ustavno teorijo in filozofijo prava, 2, 29-43. https//doi. org/10.400o/revus.1530

Schleicher, A. (2015). Helping immigrant students to succeed at school-and beyond. Paris: OECD. Accessed at https://www.oecd.org/education/ Helping-immigrant-students-to-succeed-at-school-and-beyond.pdf

Schnepf, S. V. (2007). Immigrants' educational disadvantage: an examination across ten countries and three surveys. Journal of Population Economics, 20, 527-545. https//doi.org/10.1007/s00148-006-0102-y 
Silber, M. D., \& Bhatt, A. (2007). Radicalization in the West: The homegrown threat. New York Police Department.

Skubic Ermenc, K. (2015). Izkušnje učiteljev s poučevanjem dijakov migrantskega ozadja v poklicnem izobraževanju. Andragoška spoznanja, 32(3), 7-22. https//doi.org/10.4312/as.21.3.7-22

Slodnjak, V., Kos, A., \& Yule, W. (2002). Depression and parasuicide in refugee and Slovenian adolescents. Crisis: The Journal of Crisis Intervention and Suicide Prevention, 23(3), 127-132. https//doi.org/10.1027//0227-5910.23.3.127

Tadmor, C., \& Tetlock, P. (2006). Biculturalism: A model of the effects of second-culture exposure on acculturation and integrative complexity. Journal of Cross-Cultural Psychology, 37, 173-190. https//doi. org/10.1177/0022022105284495

Vižintin,M.A.(2014).Wheredoimmigrantchildrencomefromandwhy?.Monitor ISH, 16(2), 101-126. https//doi.org/10.3370o/1580-7118.16.2.101-126(2014)

Vižintin, M. A. (2017). Medkulturna vzgoja in izobraževanje: vključevanje otrok priseljencev. ZRC SAZU.

Wigfield, A., Byrnes, J. P., \& Eccles, J. S. (2006). Development during early and middle adolescence. In Alexander, P. A., \& Winnie, P. H. (Eds), Handbook of Educational Psychology (pp. 87-113). Lawrence Erlbaum Associate Publishers.

Wiium, N., \& Dimitrova, R. (2019). Positive Youth Development Across Cultures: Introduction to the Special Issue. Child \& Youth Care Forum, 2019(48), 147-153. https//doi.org/10.1007/s10566-019-09488-7

Wortley, S. (2009). Introduction. The immigration-crime connection: Competing theoretical perspectives. Journal of International Migration and Integration/Revue de l'integration et de la migration internationale, 1o(4), 349-358. https//doi.org/10.1007/s12134-0o9-0117-9 